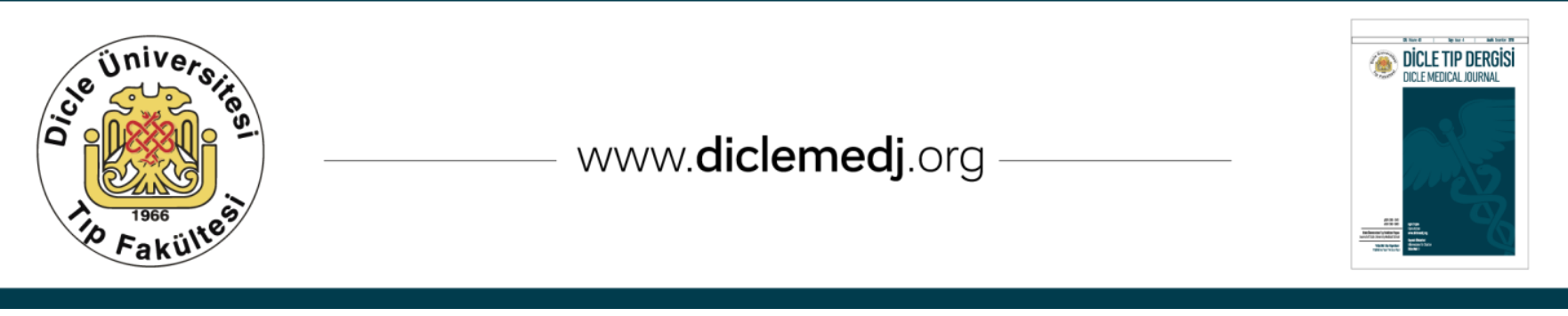

Özgün Araștırma / Original Article

\title{
İskemik İnmede TOAST ve BANFORD Sinıflaması ile Hemogram Parametrelerinin Mortalite Açısından Karşılaştırılması
}

\author{
Ayşe Sadıka Akyol1, Akkan Avci², Müge Gülen³ , Begüm Şeyda Avci', Salim Satar5 \\ 1 Ereğli Devlet Hastanesi, Acil Servis, Konya, Türkiye ORCID: 0000-0003-1620-4123 \\ 2 Sağlık Bilimleri Üniversitesi, Adana Șehir Eğitim ve Araștırma Hastanesi, Acil Tıp Kliniği, Adana, Türkiye ORCID: 0000-0002-4627-0909 \\ 3 Sağllk Bilimleri Üniversitesi, Adana Şehir Eğitim ve Araştırma Hastanesi, Acil Tıp Kliniği, Adana, Türkiye ORCID: 0000-0002-5080-3501 \\ 4 Sağlık Bilimleri Üniversitesi, Adana Şehir Ĕgitim ve Araștırma Hastanesi, İç Hastalıkları Kliniği, Adana, Türkiye ORCID: 0000-0001-6149-9341 \\ 5 Sağlık Bilimleri Üniversitesi, Adana Şehir Eğitim ve Araștırma Hastanesi, Acil Tıp Kliniği, Adana, Türkiye ORCID: 0000-0001-6080-4287
}

Geliş: 20.09.2018; Revizyon: 22.01.2019; Kabul Tarihi: 29.01.2019

\section{Öz}

Amaç: İskemik inme, mortalite ve morbiditesi yüksek, acil servis ünitelerine sık başvuran hasta grubunu oluşturmaktadır. Bu çalışmanın amacı, iskemik inme geçiren hastaların TOAST ve BANFORD sınıflaması kullanılarak risk gruplarını belirlemek, eritrosit hacmi dağılımı (RDW) ve trombosit dağılım hacmi (MPV) ile mortalite arasında ilişki olup olmadığını araştırmaktır.

Yöntemler: Çalışmaya 01.07.2014-30.06.2016 tarihleri arasında XXX Numune Eğitim ve Araştırma Hastanesi Acil Servisine başvuran ve WHO kriterlerine göre iskemik inme tanısı alan, hastaneye yatırılan ve dosya bilgileri yeterli olan 18 yaş ve üzeri hastalar alındı.

Bulgular: Çalışmaya toplam 404 hasta dahil edildi. Çalışmaya alınan 404 hastanın \%53,2'si (n=215) erkek, \%46,8'i ( $n=189)$ kadındı. Hastaların yaş gruplarına göre dağılımı incelendiğinde en büyük oranı \%57,7 (n=233) ile 65 yaş üstü grubun aldığı görüldü. Hastalar, TOAST ve Banford sınıflamasına göre gruplandırıldı. Hastaların TOAST sınıflamasına göre MPV ve RDW değerleri, sırasıyla düşük riskli grupta 8,3 $\pm 1,6,15,7 \pm 2,3$, yüksek riskli grupta ise 8,0 $\pm 1,5,16,0 \pm 2,4$ ( $p=0,096, p=0,054)$ olarak saptandı. Hastaların Banford sınıflamasına göre MPV ve RDW değerleri, sırasıyla düşük riskli grupta $7,9 \pm 1,5,15,8 \pm 1,5$, yüksek riskli grupta ise $8,2 \pm 1,6,15,9 \pm 2,6(p=0,167, p=0,943)$ olarak saptand.

Sonuç: İskemik inme tanılı hastaların acil servis yönetiminde mortaliteyi tahmin etmede hematolojik parametrelerin kullanılabilirliğini araştıran güncel araştırmalar mevcuttur. Çalışmamızda elde ettiğimiz veriler ışığında hematolojik parametrelerin, özellikle MPV ve RDW değerlerinin prognozu belirlemede etkili bir parametre olmadığı kanatine varılmıştır.

Anahtar kelimeler: İskemik İnme, TOAST, Banford, MPV, RDW

DOI: 10.5798/dicletip.534840

Yazışma Adresi / Correspondence: Akkan Avci, Sağlık Bilimleri Üniversitesi, Adana Şehir Eğitim ve Araştırma Hastanesi, Acil Tıp Kliniği, Adana, Türkiye e-mail: drakkanavci@gmail.com 


\title{
Comparison of TOAST and BAMFORD Classification and Hemogram Parameters in terms of Mortality in Ischemic Stroke
}

\begin{abstract}
Purpose: Patients with ischemic stroke who attends emergency departments frequently and have high mortality and morbidity. Purpose of this study is to determine risk groups of ischemic stroke patients by using TOAST and Banford classifications and search whether is there a relationship between red cell distribution width (RDW), mean platelet volume (MPV) and mortality.

Methods: We included patients older than 18 years old and who attend-ed XXX Numune Research and Training Hospital Emergency Department throughout two years between 01.07.2014-30.06.2016, patients aged 18 years and older who were diagnosed with ischemic stroke and hospitalized and had sufficient file information were included.

Results: We included 404 patients this study. In our study 53.2\% (n=215) of all cases were male, 46.8\% (n=189) were female. When we look patients age distribution range the biggest group was over 65 years group with $57.7 \%$ ( $\mathrm{n}=233$ ) rate. Patients were groupped according to TOAST and Banford classification. MPV and RDW values of patients according to TOAST classification were low risk group $8.3 \pm 1.6,15.7 \pm 2.3$ and high risk group $8.0 \pm 1.5,16.0 \pm 2.4$

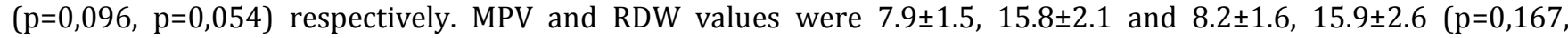
$\mathrm{p}=0,943$ ) respectively in low risk group and high risk group according to Banford classification of patients.

Conclusion: There are current studies investigating the utility of hematologic parameters in predicting mortality in emergency department management of patients with ischemic stroke. In the light of the data we obtained in our study, it was concluded that hematological parameters, especially MPV and RDW values were not an effective parameter in determining the prognosis.
\end{abstract}

Keywords: Ischemic Stroke, TOAST, Banford, MPV, RDW.

\section{GíRiş}

İnme Dünya Sağlık Örgütünün tanımlamasına göre, vasküler nedenler dişında bir görünür neden olmaksızın, beyin kan akımının bozulması sonucu fokal serebral fonksiyon kaybına ait belirti ve bulguların hızla yerleşmesi ve bu bulguların 24 saatten uzun sürmesi ile karakterize klinik bir sendromdur ${ }^{1}$.

İnme tromboz, emboli ve hemorajiyi içeren geniş bir hastalık grubunu ifade eder. Tromboz ve emboli sonucu oluşan iskemik inme tüm inmelerin \%87'sini oluşturur. İskemik inmede risk faktörleri son yıllarda yapılan uluslararası çok merkezli çalışmalar sayesinde iyi belirlenmiştir. Modifiye edilebilir risk faktörleri arasında; hipertansiyon, diabetus mellitus, sigara kullanımı, atrial fibrilasyon ve koroner arter hastalıkları sık karşıllaşılanlardır². Özellikle bu risk faktörlerinin kontrolü hastalığın seyrinde önemlidir. İskemik inmelerde etyolojik değerlendirilmenin yapılması tekrarın önlenmesi sağlamaktadır. Yeterli tanısal yöntemler olmasına rağmen önemli ölçüde nedenin saptanamadığı düşünülmektedir 3 .

İnme için birçok skorlama sistemi geliştirilmiştir. Skorlama sistemleri nörolojik sekelin ağırlığını belirtmekle kalmaz, aynı zamanda hekimler arasında ortak bir dil oluşmasına, damar tıkanıklığının yerinin belirlenmesine ve erken prognoz tahminine olanak sağlar.

Trombositlerin aterosklerotik hastalıklarda patogenezde önemli rolü olduğu bilinmektedir. Ortalama trombosit hacmi (MPV) ile ilgili miyokard infarktüsünde, kalp yetmezliğinde, pulmoner embolide, inmede ve son dönem böbrek yetmezliğinde çalışmalar yapılmıştır ${ }^{4-6}$.

Kan hemoglobin düzeyleri, eritrosit dağılım hacminin (RDW) kalp yetmezliği (KKY) ve son dönem böbrek yetmezliğinde mortalite ve morbiditede bağımsız prognostik faktör 
olmasıyla ilgili yapılmış çalışmalar mevcuttur. İnme ve miyokard infarktüsüyle ilgili de birçok çalışma vardır ${ }^{6-11}$.

$\mathrm{Bu}$ çalışmada iskemik inmeli hastalarda TOAST ve BANFORD sınıflaması kullanılarak vasküler risk faktörlerini belirlemek yanı sıra eritrosit hacmi dağılımı (RDW) ve trombosit dağılım hacmi (MPV) değerleri ile mortalite arasında ilişki olup olmadığı belirlenmeye çalışılmıştır.

\section{YÖNTEMLER}

\section{Hasta Seçimi}

Çalışmamıza 01.07.2014-30.06.2016 tarihleri arasında XXX Numune Eğitim ve Araştırma Hastanesi Acil Servisine başvuran ve WHO kriterlerine göre iskemik inme tanısı alan ve hastaneye yatırılan tüm hastalar dahil edildi. Çalışmaya başlamadan önce hastanemiz etik kurulundan onay alındı. Hastalara veya yakınlarına çalışma hakkında bilgi verilerek, sözlü ve yazılı onayları alındı. Çalışmaya toplamda 404 hasta dahil edildi.

\section{Calışmaya dahil edilme kriterleri}

İlk kez iskemik inme geçiren ve ilk 24 saat içinde acil polikliniğine başvuran, 18 yaş üzeri hastalar çalışma dahil edilmiştir.

\section{Çalışmaya dahil edilmeme kriterleri}

18 yaş altı olanlar, daha önceden iskemik inme geçirenler, çalışmaya katılmayı kabul etmeyen ve dosya verilerinde eksik bulunan hastalar olarak belirlenmiştir.

\section{Klinik ve Biyokimyasal Değerlendirme}

Serebrovasküler hastalık şüphesi ile acil servise kabul edilen hastalar monitörlü acil kritik bakım odasına alındı. Acil serviste hastaların solunum sayısı, vücut sicaklığı, arteriyel kan basıncı, nabız sayısı ve oksijen satürasyonu kaydedildi. Hastaların sistemik ve nörolojik değerlendirmesi yapıldı ${ }^{12}$. derivasyonlu EKG çekilerek ritmi kaydedildi. Hastalardan tam kan sayımı ve biyokimyasal testler için 2 ayrı tüpe 3'er ml kan alındı. Daha sonra klinik ve laboratuvar olarak iskemik inme tanısı alan hastalar için önceden hazırlamış olduğumuz form dolduruldu. Bu forma hastanın ismi, yaşı, cinsiyeti, TC numarası, hastaneye başvuru saati, acile başvuru şikâyetleri, hastanın kullandığı ilaçlar, hastanın özgeçmişi (DM, HT, iskemik kalp hastalığı, kronik böbrek yetmezliği, orak hücreli anemi, hiperlipidemi, malignensi, asemptomatik karotis darlık ve sigara/alkol kullanımı) kaydedildi. Acil servisimizde çekilmiş olan ve radyoloji uzmanı tarafından yazılı olarak raporlanan BT ve MR'daki infarkt lokalizasyonu kayıt altına alındı. Tetkiklerde, hemoglobin, hematokrit (Hct), trombosit, ortalama trombosit hacmi (MPV), eritrosit dağılım hacmi (RDW), glukoz, üre, kreatinin düzeyleri kaydedildi. Bu bulgularla klinik ve laboratuvar olarak iskemik inme tanısı konan hastalar nöroloji tarafından servis veya yoğum bakıma alınarak tedavilerine devam edildi. Son olarak hastaların yattıkları klinikte kaç gün kaldıkları ve sonlanımları kayıt altına alındı.

\section{İstatistiksel Analiz}

Verilerin tanımlayıcı istatistiklerinde ortalama, standart sapma, medyan en düşük, en yüksek, frekans ve oran değerleri kullanılmıștır. Değişkenlerin dağılımı kolmogorov simirnov test ile ölçüldü. Nicel bağımsız verilerin analizinde bağımsız örneklem $t$ test, mannwhitney $\mathrm{u}$ test kullanıldı. Nitel bağımsız verilerin analizinde ki-kare test kullanıldı. Grupların karşılaştırılmasında p değeri 0,05 altındaki değerler anlamlı kabul edildi. Analizlerde SPSS 22.0 programı kullanıldı.

\section{BULGULAR}

Çalışmamıza toplam 404 hasta dahil edildi. Hastaların \%53,2'si $(n=215)$ erkek, \%46,8'i $(\mathrm{n}=189)$ kadındı. Hastaların yaş gruplarına göre dağılımı incelendiğinde en büyük oranı \%57,7 $(n=233)$ ile 65 yaş üstü grubun aldığı görüldü. 51-65 yaş arası hastalar \%33,7 $(n=136)$ oranında, 30-50 yaş arası hastalar ise \%8,7 $(\mathrm{n}=33)$ oranındaydı. Hastaların yaş ortalaması $67,0 \pm 12,4$ olarak saptandl. 
Hastaların acil serviste çekilen EKG'lerinde $\% 68,8 \quad(\mathrm{n}=278)$ normal sinüs ritmi, $\% 15,8$ $(\mathrm{n}=64)$ atrial fibrilasyon, \%5,4 $(\mathrm{n}=22), \% 1,7$ $(\mathrm{n}=7)$ blok ve $\% 0,5(\mathrm{n}=2)$ sinüs bradikardisi saptandl. Hastaların \%7,7'sinin $(\mathrm{n}=31)$ EKG verilerine ulaşılamadı (Tablo 1).

Tablo 1: Hastaların EKG bulguları

\begin{tabular}{|lcc|}
\hline & n & \% \\
\hline Sinüs ritmi & 278 & 68,8 \\
Sinüs taşikardisi & 22 & 5,4 \\
EKG Sinüs bardikardisi & 2 & 0,5 \\
Atriyal fibrilasyon & 64 & 15,8 \\
Blok & 7 & 1,7 \\
Çekilmedi & 31 & 7,7 \\
\hline
\end{tabular}

Acil serviste BBT çekilen hastaların $\% 59,7$ 'sinde $(\mathrm{n}=241)$ BT iskemi ile uyumluydu, $\% 40,1$ 'inde $(\mathrm{n}=162)$ ise BT normal olarak saptandl.

Hastaların \%49'unda ( $\mathrm{n}=198)$ MR'da iskemik bulgular mevcutken \%3,7'sinde ( $\mathrm{n}=15)$ MR'da iskemiye rastlanmadı. Dönemsel olarak karşılaşılan teknik sorunlar nedeniyle ve BT normal iken klinik olarak iskemik inme düşünülen \%39,6 (n=160) oranında hastaya MR görüntüleme istenmedi.

Tablo 2: Hastaların ortalama laboratuvar değerleri

\begin{tabular}{|lccc|}
\hline & Min-Mak & Medyan & Ort \pm ss./n\% \\
\hline HTC & $16,3-52,0$ & 39,7 & $39,4 \pm 4,9$ \\
HGB & $5,1-17,9$ & 13,1 & $13,0 \pm 1,7$ \\
PLT & $2,5-632,0$ & 238,5 & $245,4 \pm 83,3$ \\
MPV & $5,2-14,7$ & 7,8 & $8,1 \pm 1,6$ \\
RDW & $11,3-39,2$ & 15,4 & $15,9 \pm 2,4$ \\
Glukoz & $68,0-571,0$ & 142,0 & $170,1 \pm 85,2$ \\
Üre & $1,6-128,1$ & 36,4 & $39,6 \pm 16,5$ \\
Kreatinin & $0,4-79,7$ & 0,9 & $1,2 \pm 4,0$ \\
\hline
\end{tabular}

İnme tanısıyla hastaneye yatırılan hastaların \%98,5'i (n=398) taburcu oldu, \%1,5'i (n=6) hasta exitus oldu. Hastalarin hastanede ortalama yatış süresi $4,7 \pm 8,0$ gündü.

Hastalara ait hemogram, glukoz, kan üre azotu ve kreatinin değerleri Tablo 2'de belirtildi.

TOAST sinıflamasına göre değerlendirilen hastalardan geniş arter aterosklerozu olanlar ve doppler USG'deki darlık oranı ve \%50'den az olan ve geniş enfarkta neden olabilecek kardiyoembolizm düşünülen hastalar yüksek riskli, diğer gruplardaki hastalar ise düşük riskli olarak sinıflandırıldı.

TOAST sinıflamasina göre riskli grupta hastaların yaşları düşük riskli gruptan anlamlı ( $\mathrm{p}<0,05)$ olarak daha düşüktü. TOAST sınıflamasına göre riskli ve düşük riskli grupta hastaların cinsiyet dağılımı, hastaneye geliş saat dağılımı, alkol ve sigara kullanım oranı anlamlı $(p>0,05)$ farklılık göstermediğ saptandı (Tablo 3).

Tablo 3: Riskli ve düşük riskli hastaların TOAST sınıflamasına göre karşılaștırılması

\begin{tabular}{|c|c|c|c|c|c|c|}
\hline & & \multicolumn{4}{|c|}{ TOAST Sinıflandırması } & \multirow{3}{*}{$\mathbf{p}$} \\
\hline & & \multicolumn{2}{|c|}{ Düşük Riskli Grup } & \multicolumn{2}{|c|}{ Riskli Grup } & \\
\hline & & $\begin{array}{c}\text { Ort+ss/n- } \\
\% \\
\end{array}$ & Med & $\begin{array}{c}\text { Ort+ss/n- } \\
\% \\
\end{array}$ & Med & \\
\hline Yaş & & $64,3 \pm 12,3$ & 63,0 & $69,0 \pm 12,1$ & 71,0 & $0,000^{\mathrm{m}}$ \\
\hline \multirow{3}{*}{ Yaş grup } & $30-50$ & 18 & $\% 10,7$ & 17 & $\% 7,2$ & \multirow{3}{*}{$0,000^{x^{2}}$} \\
\hline & $51-65$ & 74 & $\% 43,8$ & 62 & $\% 26,4$ & \\
\hline & $>65$ & 77 & $\% 45,6$ & 156 & $\% 66,4$ & \\
\hline \multirow{2}{*}{ Cinsiyet } & Kadın & 78 & $\% 46,2$ & 111 & $\% 47,2$ & \multirow{2}{*}{$0,830^{\mathrm{x} 2}$} \\
\hline & Erkek & 91 & $\% 53,8$ & 124 & $\% 52,8$ & \\
\hline \multirow{3}{*}{$\begin{array}{l}\text { Hastaneye } \\
\text { geliş saati }\end{array}$} & 00:00/08:00 & 14 & $\% 8,3$ & 22 & $\% 9,4$ & \multirow{3}{*}{$0,318^{x}$} \\
\hline & 08:00/18:00 & 101 & $\% 59,8$ & 154 & $\% 65,5$ & \\
\hline & 18:00/24:00 & 54 & $\% 32,0$ & 59 & $\% 25,1$ & \\
\hline \multirow{2}{*}{$\begin{array}{l}\text { Alkol } \\
\text { kullanımı }\end{array}$} & Var & 26 & $\% 15,4$ & 33 & $\% 14,0$ & \multirow{2}{*}{$0,706^{\mathrm{x} 2}$} \\
\hline & Yok & 143 & $\% 84,6$ & 202 & $\% 86,0$ & \\
\hline \multirow{2}{*}{$\begin{array}{l}\text { Sigara } \\
\text { kullanımı }\end{array}$} & Var & 65 & $\% 38,5$ & 80 & $\% 34,0$ & \multirow{2}{*}{$0,361^{\mathrm{x} 2}$} \\
\hline & Yok & 104 & $\% 61,5$ & 155 & $\% 66,0$ & \\
\hline
\end{tabular}


TOAST sınıflamasına göre riskli ve düşük riskli grupta eksitus ile sonlanım oranı anlamlı farklılık $(p>0,05)$ göstermedi. HTC, HGB, PLT, MPV, RDW, kan glukoz ve kreatinin değerleri yüksek riskli ve düşük riskli grup karşılaștırılmasında anlamlı ( $p>0,05)$ farklılık göstermediği tespit edildi. TOAST sınıflamasına göre yüksek riskli grupta olan hastaların üre değeri düşük riskli gruptan anlamlı $(p=0.001)$ olarak daha yüksekti (Tablo 4).

Tablo 4: TOAST sınıflamasına göre riskli-düşük riskli hastaların laboratuvar değerlerinin karşılaştırılması

\begin{tabular}{|c|c|c|c|c|c|c|c|c|c|}
\hline \multirow[b]{4}{*}{ HTC } & \multicolumn{8}{|c|}{ TOAST Sinıflandırması } & \multirow{4}{*}{$\begin{array}{c}\mathbf{p} \\
0,231^{\mathrm{m}}\end{array}$} \\
\hline & \multicolumn{4}{|c|}{ Düşük Riskli Grup } & \multicolumn{4}{|c|}{ Riskli Grup } & \\
\hline & \multicolumn{3}{|c|}{ Ort. \pm s.s. } & \multirow{2}{*}{$\begin{array}{c}\text { Med } \\
40,1\end{array}$} & \multicolumn{3}{|c|}{ Ort. \pm s.s. } & \multirow{2}{*}{$\begin{array}{c}\text { Med } \\
39,4\end{array}$} & \\
\hline & 39,8 & \pm & 4,5 & & 39,1 & \pm & 5,1 & & \\
\hline HGB & 13,1 & \pm & 1,6 & 13,2 & 12,9 & \pm & 1,8 & 13,0 & $0,465^{\mathrm{m}}$ \\
\hline PLT & 250,1 & \pm & 77,8 & 243,0 & 242,1 & \pm & 87,1 & 236,0 & $0,345^{\mathrm{m}}$ \\
\hline MPV & 8,3 & \pm & 1,6 & 7,9 & 8,0 & \pm & 1,5 & 7,7 & $0,096^{\mathrm{m}}$ \\
\hline RDW & 15,7 & \pm & 2,3 & 15,3 & 16,0 & \pm & 2,4 & 15,5 & $0,054^{\mathrm{m}}$ \\
\hline Glukoz & 165,8 & \pm & 88,6 & 139,0 & 173,3 & \pm & 82,7 & 144,0 & $0,168^{\mathrm{m}}$ \\
\hline Üre & 36,5 & \pm & 14,6 & 34,4 & 41,8 & \pm & 17,4 & 38,0 & $\mathbf{0 , 0 0 1}{ }^{\mathrm{m}}$ \\
\hline Kreatinin & 1,4 & \pm & 6,1 & 0,9 & 1,1 & \pm & 0,6 & 0,9 & $0,077^{\mathrm{m}}$ \\
\hline
\end{tabular}

TOAST sınıflamasına göre yüksek riskli grupta EKG'de atriyal fibrilasyon ve blok görülme oranı düşük riskli gruptan anlamlı $(\mathrm{p}=0,003)$ olarak daha yüksekti. TOAST sınıflamasına göre BT de inme görülme oranı riskli ve az riskli grup arasinda anlamlı (p>0,05) farklılık göstermedi. TOAST sinıflamasında göre riskli grupta MR da inme görülme oranı az riskli gruptan anlamlı $(\mathrm{p}<0,001)$ olarak daha yüksekti (Tablo 5).

Hastalar infarkt hacmi ve klinik seyri göz önüne alınarak total anterior sirkülasyon infarktları (TACI) riskli, diğer grupta olan hastalar ise düşük riskli olarak sinıflandırıldı.

Banford sinıflamasına göre riskli gupta olan hastaların yaş ortalaması ile düşük riskli grupta olan hastaların yaş ortalaması arasında fark bulunamadı $(p>0,05)$. Banford siniflamasina göre riskli ve düşük riskli grupta hastaların cinsiyet dağılımı anlamlı ( $p>0,05)$ farklılık göstermedi.
Tablo 5: Hastaların EKG, BT ve MR sonuçlarının TOAST sınıflamasına göre karşılaştırılması

\begin{tabular}{|c|c|c|c|c|c|c|}
\hline & & \multicolumn{4}{|c|}{ TOAST Sınıflandırması } & \multirow{3}{*}{$\mathbf{p}$} \\
\hline & & \multicolumn{2}{|c|}{$\begin{array}{l}\text { Düşük Riskli } \\
\text { Grup }\end{array}$} & \multicolumn{2}{|c|}{ Riskli Grup } & \\
\hline & & $\mathrm{n}$ & $\%$ & $\mathrm{n}$ & $\%$ & \\
\hline \multirow{6}{*}{ EKG } & Sinüs ritmi & 130 & $\% 85,0$ & 148 & $\% 67,3$ & \multirow{6}{*}{$0,003^{x 2}$} \\
\hline & $\begin{array}{l}\text { Sinüs } \\
\text { taşikardisi }\end{array}$ & 7 & $\% 4,6$ & 15 & $\% 6,8$ & \\
\hline & $\begin{array}{l}\text { Sinüs } \\
\text { bardikardisi }\end{array}$ & 0 & $\% 0,0$ & 2 & $\% 0,9$ & \\
\hline & $\begin{array}{l}\text { Atriyal } \\
\text { fibrilasyon }\end{array}$ & 14 & $\% 9,2$ & 50 & $\% 22,7$ & \\
\hline & Blok & 2 & $\% 1,3$ & 5 & $\% 2,3$ & \\
\hline & Çekilmedi & 16 & & 15 & & \\
\hline \multirow{3}{*}{ BT } & İnme & 105 & $\% 62,1$ & 136 & $\% 58,1$ & \multirow{3}{*}{$0,418^{\times 2}$} \\
\hline & Normal & 64 & $\% 37,9$ & 98 & $\% 41,9$ & \\
\hline & Çekilmedi & 0 & & 1 & & \\
\hline \multirow{3}{*}{ MR } & İnme & 87 & $\% 86,1$ & 111 & $\% 99,1$ & \multirow{3}{*}{$0,000^{x^{2}}$} \\
\hline & Normal & 14 & $\% 13,9$ & 1 & $\% 0,9$ & \\
\hline & Çekilmedi & 53 & & 107 & & \\
\hline
\end{tabular}


Banford sınıflamasına göre riskli ve düşük riskli grupta alkol kullanım oranı anlamlı ( $>0,05)$ farklılı göstermedi. Banford sınıflamasına göre yüksek riskli grupta sigara kullanım oranı düşük riskli gruptan anlamlı $(p=0,02)$ olarak daha düşüktü (Tablo 6).

Tablo 6: Banford sınıflamasına göre riskli ve düşük riskli hastaların demografik verilerinin karşılaştırılması

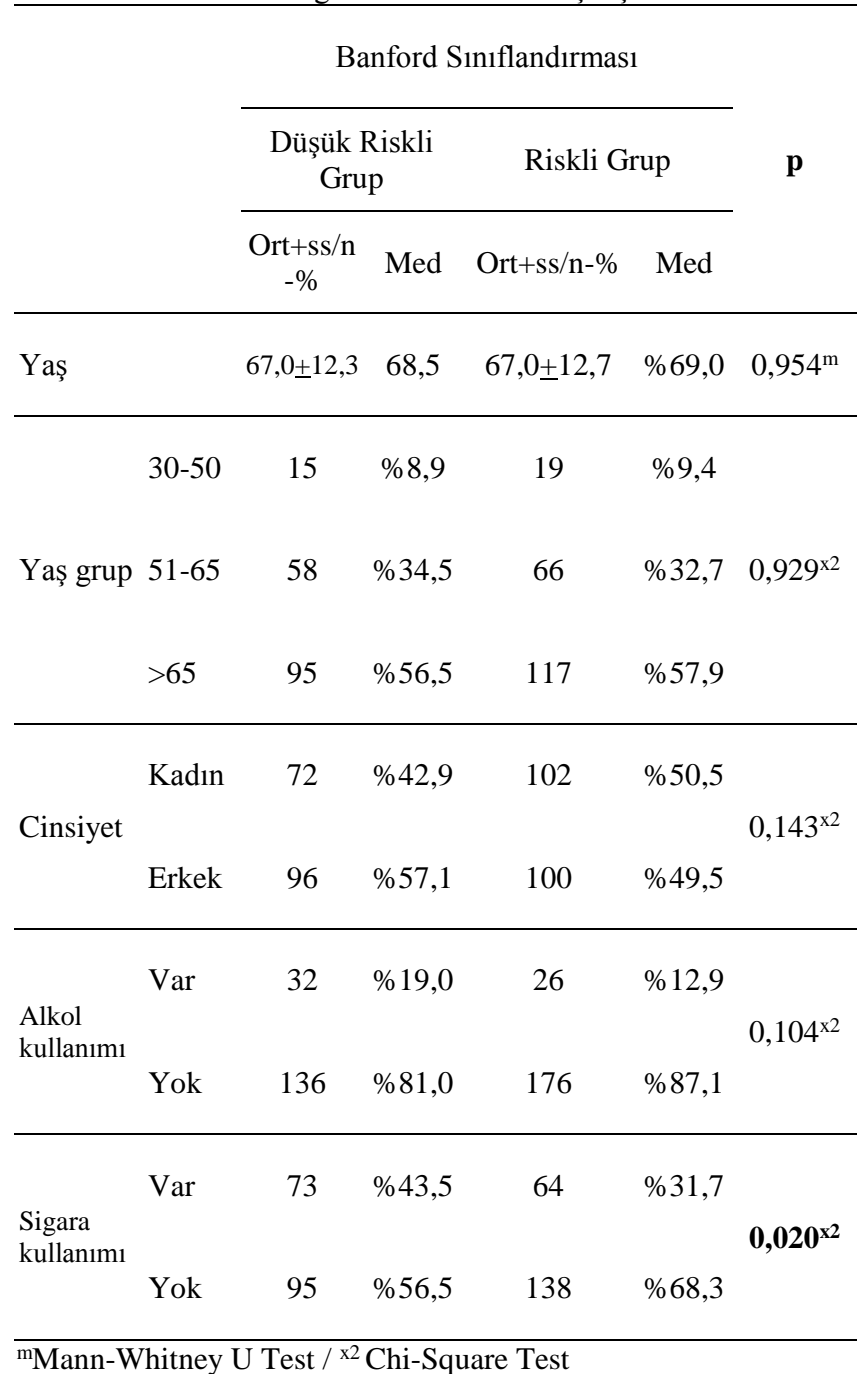

Banford sinıflamasına göre riskli ve az riskli grup arasinda hemoglobin, hematokrit, trombosit, MPV, RDW, glukoz, kreatinin ve üre değerlerinde anlamlı $(p>0,05)$ farklılık göstermedi (Tablo 7).
Banford sinıflamasına göre riskli ve az riskli grup arasinda EKG bulguları anlamlı ( $p>0,05)$ farklılık göstermedi. Banford sınıflamasına göre riskli grupta BT de inme görülme oranı az riskli gruptan anlamlı $(\mathrm{p}<0,001)$ olarak daha yüksekti. Banford sınıflamasına göre riskli grupta MR da inme görülme oranı az riskli gruptan anlaml $(\mathrm{p}=0,001)$ olarak daha yüksekti (Tablo 8).

\section{TARTIŞMA}

İskemik inme tüm dünyada yaygın görülen ve gelişmiş ülkelerde kanser ve kalp hastalıklarından sonra ölümün ${ }^{3}$ en sık nedeni olarak tanınan bir hastalıktır. İskemik inmede yaş ve cinsiyet önemli epidemiyolojik faktörlerdir. İnme ile ilgili en belirleyici unsur yaştır. İnme insidansı oranları erkeklerde kadınlardan daha yüksektir ve ileri yaşlarda kadınlar arasındaki hız daha fazladır.

Literatürde iskemik inmeli hastaların yaş ve cinsiyet dağılımları hakkında birçok veri mevcuttur. Yapılan bir çalışmada yaş ortalamasının 72 olduğunu, olguların \%56,1'inin erkek olduğunu tespit etmişlerdir ${ }^{12}$. Başka bir çalışmada hastaların yaş ortalaması $63,7 \pm 14,54$ olarak tespit edilmiş ve \%51'inin erkek olduğu saptanmıştır ${ }^{13}$. İskemik inmeli hastalarla yapılan başka bir çalışmada hastaların yaş ortalamasını 69,5 $\pm 12,8$ olarak tespit edilmiş ve hastaların \%51'inin erkek olduğunu belirtilmiştir ${ }^{14}$. Bizim çalışmamızda da literatürle uyumlu cinsiyet dağılımı ve yaş ortalaması değerleri elde ettik.

Acil servise başvuran akut iskemik inmeli hastaları bir yıllık geriye dönük inceleyen bir çalışmada hastaların \%31,5'inde normal sinüs ritmi, \%11,3'ünde atrial fibrilasyon, bir hastada ventriküler ekstrasistol ve bir hastada da pace ritmi tespit etmişlerdir ${ }^{15} .2008$ yılında yayınlanan başka bir çalışmada hastaların \%78'inde normal sinüs ritmi, \%22'sinde de atrial fibrilasyon saptanmıştır ${ }^{16}$. Bulgularımız diğer çalışmalarla uyumluydu. Hastaları TOAST sınıflamasına göre değerlendirdiğimizde riskli 
grupta atriyal fibrilasyon ve blok gibi EKG değişiklerini düşük riskli gruptan anlamlı olarak daha yüksek olarak saptadık. Banford sinıflamasına göre hastaları değerlendirdiğimizde ise riskli ve düşük riskli grup arasında EKG bulguları açısından anlamlı fark saptamadık. Kardiyovasküler hastalıklar inme riskini artırsa da inmenin kendisi de aritmilere neden olur. Riskli hastalarda az riskli gruba göre daha fazla EKG değişikliğini bu şekilde açıklamak mümkündür. Ayrıca riskli hastalarda görülen bradikardi ve blok gibi ritimlerde Cushing refleksinin triadı olan bradikardi, artmış solunum hızı, hipertansiyon ve kafa içi basınç artışı sendromu bulguları akla getirilmelidir. Riskli hastalarda EKG bulguları arasındaki fark, bu hastaların kafa içi basınç artışına daha yatkın olmalarından kaynaklanıyor olabilir.

Tablo 7: Banford sınıflamasına göre riskli-az riskli gruplarda laboratuvar değerlerinin karşılaştırılması

\begin{tabular}{|c|c|c|c|c|c|c|c|c|c|}
\hline \multirow[b]{4}{*}{ HTC } & \multicolumn{8}{|c|}{ Banford Sınıflandırması } & \multirow{3}{*}{$\mathbf{p}$} \\
\hline & \multicolumn{4}{|c|}{ Düşük Riskli Grup } & \multicolumn{4}{|c|}{ Riskli Grup } & \\
\hline & \multicolumn{3}{|c|}{ Ort. \pm s.s. } & \multirow{2}{*}{$\begin{array}{c}\text { Med } \\
40,0\end{array}$} & \multicolumn{3}{|c|}{ Ort. \pm s.s. } & \multirow{2}{*}{$\begin{array}{c}\text { Med } \\
39,4\end{array}$} & \\
\hline & 39,5 & \pm & 5,1 & & 39,2 & \pm & 4,7 & & $0,229^{\mathrm{m}}$ \\
\hline HGB & 13,0 & \pm & 1,8 & 13,2 & 12,9 & \pm & 1,6 & 13,1 & $0,313^{\mathrm{m}}$ \\
\hline PLT & 251,4 & \pm & 86,1 & 243 & 242,2 & \pm & 84,1 & 239,5 & $0,479^{\mathrm{m}}$ \\
\hline MPV & 7,9 & \pm & 1,5 & 7,6 & 8,2 & \pm & 1,6 & 7,8 & $0,167^{\mathrm{m}}$ \\
\hline RDW & 15,8 & \pm & 2,1 & 15,4 & 15,9 & \pm & 2,6 & 15,4 & $0,943^{\mathrm{m}}$ \\
\hline Glukoz & 177,0 & \pm & 94,8 & 144,0 & 164,1 & \pm & 77,6 & 141,0 & $0,406^{\mathrm{m}}$ \\
\hline Üre & 39,4 & \pm & 17,3 & 35,3 & 40,1 & \pm & 16,2 & 37,6 & $0,409^{m}$ \\
\hline Kreatinin & 1,5 & \pm & 6,1 & 0,9 & 1,0 & \pm & 0,5 & 0,9 & $0,371^{\mathrm{m}}$ \\
\hline
\end{tabular}

Sigara içilmesi inme riskini yaklaşık 2 kat arttırır. İçilen miktar arttıkça risk de artmaktadır ${ }^{17}$. Alkol kullanımı ile inme arasında "J" şeklinde bir iliş̧i vardır ${ }^{18} .2003$ yılında yayınlanan bir çalışmada hastaların $\% 28,5$ 'inin sigara kullandığını belirtmişlerdir ${ }^{18} .2009$ yılında yayınlanan iskemik inmeli hastaları geriye dönük incelen bir çalışmada hastaların $\% 18,5$ 'inin sigara ve \%5,6'sinın alkol kullandığını belirtilmiştir ${ }^{15}$. Banford sınıflamasına göre riskli grupta sigara kullanım oranı düşük riskli gruptan anlamlı olarak daha düşüktü. Alkol kullanımı Banford sınıflamasına göre riskli ve düşük riskli grup arasında anlamlı farklılık göstermedi.
İskemik inmeli hastaların BT bulgularının değerlendirildiği bir çalışmada hastaların \%80,6'sında BT bulgusu olmadığını ifade etmişlerdir ${ }^{19}$. Çalışmamızda hastaların $\% 59,7$ 'sinde BT inme ile uyumluyken $\% 40,1$ 'inde BT normaldi. Bulgular arasındaki bu fark hastaların inme semptomlarının başlaması ile acil serviste BT çekilmesi arasında geçen süre ve bu sürede BT bulgularının oluşması ile ilgili olabilir. TOAST sınıflamasına göre riskli ve düşük riskli grupta BT'de inme görülme oranı açısından anlamlı fark saptamadık. Banford sınıflamasına göre değerlendirildiğinde riskli grupta BT'de inme görülme oranını düșük riskli gruptan anlamlı olarak yüksek saptadık. İnfarkt hacmi ve süresi BT'de inme bulgularının ortaya çıkmasında etkendir. Bizim çalıșmamızda da bununla uyumlu olarak infarkt hacmi büyük olan yüksek 
riskli hastalarda $\mathrm{BT}$ 'de inme görülme oranında anlamlı farklılık elde ettik.

Yapılan bir çalıșmada hastaların \%85'inin diffüzyon ağırlıklı MR görüntülemesinin inme ile uyumlu olduğunu saptamışlar ${ }^{20}$. Bizim çalışmamızda hastaların \%49'unda (n=198) MR'da inme saptandı. Hastaların \%39,6'sına $(n=160)$ dönemsel olarak yaşanan teknik yetersizlikler ve hastaların metal protez öyküleri nedeniyle MR çekilemedi. Klinik olarak inme ile uyumlu olan ve BT'de klinikle uyumlu inme bulguları saptanan hastalara MR çekilemedi. Hastaların bulguları TOAST sınıflamasına göre değerlendirildiğinde riskli grupta MR'da inme görülme oranı düşük riskli gruptan anlamlı olarak daha yüksekti. Banford sınıflamasına göre riskli grupta MR'da inme görülme oranı düşük riskli gruptan anlamlı olarak daha yüksekti.

Tablo 8: Banford sınıflamasına göre riskli ve düşük riskli grupların EKG, BT, MR sonuçlarının karşılaştırılması

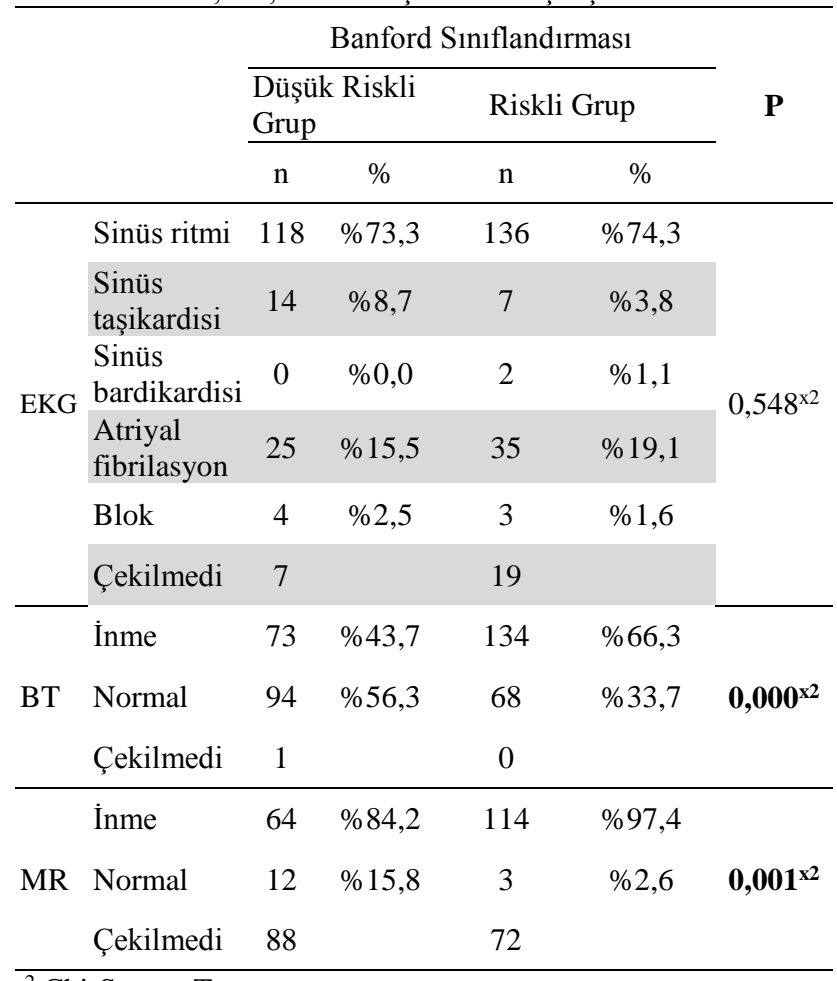

$\mathrm{x}^{2}$ Chi-Square Test
RDW ve MPV rutin kan sayımında çalıșlan parametrelerdir. Trombositler aterosklerotik olayların patogenezinde ve trombüs oluşumunda önemli rol oynamaktadır ${ }^{21}$. MPV; trombosit büyüklügü, trombosit agregasyonu, tromboksan A2, trombosit faktör 4 ve tromboglobulin salınımı gibi trombositlere özgü aktiviterlerin iyi bir göstergesidir ${ }^{22}$. Büyük trombositler daha reaktiftir, daha fazla protrombotik faktör üretir ve daha kolay yapışırlar ${ }^{23}$. MPV'nin diyabette, koroner arter hastalığı gibi durumlarda arttığı gösterilmiş, iskemik inme ile ilgili yapılan çalıșmalarda da MPV artışı ile iskemik inme geçirme riskinin arttığı ve prognozun kötüleştiği bildirilmiştir ${ }^{24}$. O’Malley ve arkadaşları akut iskemik inmede MPV düzeyini normalden büyük bulmușlar fakat laküner infarkt ve büyük damar hastalığı grupları arasında bir farklılık tespit etmediklerini bildirmişlerdir ${ }^{25}$. Toghi ve arkadaşları akut iskemik inmede MPV düzeyini kontrol grubuna göre daha düșük düzeyde bulduklarını, çalışmalarında hasta sayısının az olmasindan dolayı inme alt tipleri arasinda istatistik yapamadıklarını ifade etmişlerdir. Ayrıca MPV düzeyinin düşüklüğünü büyük trombositlerin serebral tromboz anında tüketilmesi ile açıklamışlardır ${ }^{26}$. İskemik inme ile periferik kan hücrelerinin ilișkisini araștıran bașka bir çalışmada iskemik inmeli hastalarda MPV değerini istatistiksel olarak anlamlı olacak şekilde yüksek bulmuşlar, inme alt tipleri ile karşılaștırıldığında ise istatitiksel olarak anlamlı sonuç çıkmadığını belirtmişlerdir ${ }^{14}$. İnme alt tipleri ile MPV değerini karşılaştıran başka bir çalışmada, laküner infarkt grubunda MPV değerlerini kontrol grubundan farksız bulurken, büyük damar hastalığına bağlı kortikal infarkt grubunda anlamlı olarak büyük bulmuşlardır27. Güldiken ve arkadaşları ise akut iskemik inmede MPV düzeylerinde anlamlı bir yükseklik tespit etmediklerini ifade etmişlerdir ${ }^{28}$. Etiyolojik açıdan TOAST sınıflamasına göre daha riskli kabul ettiğimiz büyük damar hastalığı grubu ve kardiyoembolizm grubunda daha düşük riskli 
kabul ettiğimiz laküner enfarkt ve nedeni bilinmeyen enfarkt grupları arasında MPV düzeylerinde istatistiksel olarak anlamlı fark saptamadık. İnme alt tipleri ile ilgili bulgularımız literatürle uyumluydu. İnfarkt büyüklügü ve yerleşimi ile değerlendirilen Banford sınıflamasına göre riskli ve düşük riskli inme alt tipleri arasinda ortalama MPV düzeyleri arasında anlamlı farklılık saptamadık. Araştırmaların sonuçları arasındaki farklılık inme alt gruplandırmasında farklı kriterler kullanılmasına bağlı olabileceği gibi, ölçüm yöntemi farklılıklarına ve grupların az sayıda hastadan oluşmasına bağlı olabilir. Alınan kanın EDTA'lı tüpler içinde bekletildiği süre içinde trombositlerin hacim kazandığ bilinmektedir. Çalıșmamızda alınan kanlar dört saat gibi kısa zamanda ölçülmüş, ancak diğer çalışmalarda da olduğu gibi zamana bağlı bir düzeltme yapılmamıştır. MPV değerlerinin iskemik inme hadiselerinde etkinliği halen tartışma konusu olmakla beraber elde ettiğimiz veriler MPV değerlerinin iskemik inmede bir belirteç olarak kullanılmasının uygun olmadığı görüşündeyiz.

2009 yılında yayınlanan bir çalışmada inme geçiren hastalarda ortalama RDW değerinin normal popülasyondan daha yüksek olduğunu ve inme geçirenleri kendi içlerinde karşılaştırdıklarında kardiyovasküler ve tüm nedenlere bağlı ölümlerde RDW değerinin artmasıyla mortalitenin de arttığını saptamışlardır. İnme geçirmiş hastalarda RDW yüksekliğini mortalitede bağımsız bir risk faktörü olarak belirtmişler. RDW değeri yüksek inme geçirmemiş hastalarda da inme geçirme riskinin arttığını belirtmişlerdir ${ }^{29}$. Eritrosit dağılım genişliğinin akut iskemik inmede nörolojik skorlamalarla ilişkisinin gösterildiği 2015 yılında yayınlanan bir çalışmada; 24 saat içinde acile başvuran hastalarda RDW değerlerinin inmenin şiddeti ile pozitif korelasyon gösterdiği saptanmıştır ${ }^{30}$. Periferik kan hücreleri ve inme şiddetini araştıran başka bir çalışmada RDW düzeylerini istatiksel olarak anlamlı çıkacak şekilde yüksek bulduklarını ancak inme alt tipleri arasında karşılaştırma yaptıklarında anlamlı bir sonuç bulmadıklarını belirtmişlerdir ${ }^{14}$. Bizim çalışmamızda iskemik inmeli hastalarda ortalama RDW düzeylerinde istatistiksel olarak anlamlı bir yükseklik saptamadık. TOAST sinıflamasına göre yüksek riskli kabul ettiğimiz geniş arter aterosklerozu ve kardiyoembolizm grubu ile düşük riskli kabul ettiğimiz laküner infarkt ve nedeni bilinmeyen infarkt grubu arasında ortalama RDW düzeyleri açısından anlamlı bir fark saptamadık. Hastaları Banford sınıflamasına göre, riskli ve düşük riskli grup arasında RDW düzeyleri açısından anlamlı fark saptamadık. Çalışma sonuçları arasındaki farklılık inme alt grupları değerlendirilirken farklı ölçütler kullanılmasına, ölçüm yöntemi farklılıklarına ve gruplardaki hasta sayısının az olmasına bağlı olabilir. İskemik inmeli hastalarda periferik kan hücrelerinin ve RDW düzeylerinin inme sonrası erken dönemde çalışıldığında anlamlı olduğu bilinmektedir. Bizim çalışmamızda ilk 24 içinde başvuran hastalar değerlendirildi. Çalışmalar arasındaki RDW değerleri arasındaki farklılık başvuru ve kanın alınma saatine de bağlı olabilir. RDW düzeyleri ile iskemik inme arasında korelasyon olduğunu iddia eden araştırmalar olsa da elde ettiğimiz veriler daha çok ilişki olmadığını savunan araştırmalarla uyumlu olduğunu tespit ettik.

\section{SONUÇ}

İskemik inme acil serviste sık karşılaşılan ciddi mortalite ve morbiditeye neden olan nörolojik bir tablodur. $\mathrm{Bu}$ hasta grubunun acil yönetiminde mortaliteyi tahmin etmede hematolojik parametrelerin kullanılabileceği savını savunan çalışmalar olsa da bunun aksini ifade eden araştırmalar da mevcuttur. $\mathrm{Bu}$ çalışmamızda elde ettiğimiz veriler ışığında hematolojik parametrelerin, özellikle MPV ve RDW değerlerinin kullanım etkinliğinin uygun olmadığı düşüncesindeyiz. 
Çıkar Çatışması Beyanı: Yazarlar çıkar çatışması olmadığını bildirmişlerdir.

Finansal Destek: Bu çalıșma her hangi bir fon tarafından desteklenmemiştir.

Declaration of Conflicting Interests: The authors declare that they have no conflict of interest.

\section{Financial Disclosure: No financial support} was received.

\section{KAYNAKLAR}

1. Hatano S. Experience from a multicenre stroke register: preliminary report. Bull World Health Organ. 1976; 54: 541-53.

2. Bos MJ, Koudstaal PJ, Hofman A, et all. Modifiable etiologial factors and the burden of stroke from the rottedam study: a population based cohort study. 2014; 11.

3. Kurşun HK. İntrasellüler sinyalleşme: mediatörler ve protektif yanitlarda bozulma. Edt Kumral E. Santral Sinir Sisteminin Damarsal Hastalıkları. (s. 275308). Ankara: Güneş Tıp Kitabevi, 2011.

4. Butterworth RJ, Bath PM. The relationship between mean platelet volume, stroke subtype and clinical outcome. Platelets. 1998; 9: 359-64.

5. Greisenegger S, Endler G, Hsieh K, et all. Is elevated mean platelet volume associated with a worse outcome in patients with acute ischemic cerebrovascular events? Stroke; a journal of cerebral circulation. 2004; 35: 1688-91.

6. Ani C, Ovbiagele B. Elevated red blood cell distribution width predicts mortality in persons with known stroke. Journal of the neurological sciences. 2009; 277: 103108.

7. Tonelli M, Sacks F, Arnold M. Relation Between Red Blood Cell Distribution Width and Cardiovascular Event Rate in People With Coronary Disease. Circulation. 2008; 117: 163-8.

8. Felker GM, Allen LA, Pocock SJ. Red cell distribution width as a novel prognostic marker in heart failure: data from the CHARM Program and the Duke Databank. J Am Coll Cardiol. 2007; 50: 40-7.

9. Cantaro S, Piva E. [Hematological and iron parameters to predict mortality in ESRD]. Giornale italiano di nefrologia : organo ufficiale della Societa italiana di nefrologia. 2005; 22: 135-9.
10. Furlan JC, Fang J, Silver FL. Acute ischemic stroke and abnormal blood hemoglobin concentration. Acta Neurol Scand. 2015.

11. Kellert L, Kloss M, Pezzini A. Anemia in young patients with ischaemic stroke. European journal of neurology: The official journal of the European Federation of Neurological Societies. 2015; 22: 948-53.

12. Ntaisos G, Gürer Ö, Faouzi M, et all. Red cell distribution width does not predict stroke severity or functional outcome. International Journal of Stroke \& 2011 World Stroke Organization 2012; 7: 2-6.

13. Bath PM, Butterworth RJ. Platelet size: Measurement, physiology and vascular disease. Blood Coagul Fibrinolysis. 1996; 7: 157-61.

14. Acar E, Tanrıkulu CS, Karaman S, et all. Akut inme ile periferik kan hüre sayısının ilişkisi. Silk Road Med J. 2015; 1: 7-12.

15. Kıyan S, Özsaraç M, Ersel M, et all. Acil Servise Başvuran Akut İskemik İnmeli 124 Hastanın Geriye Yönelik Bir Yıllık İncelenmesi. Akademik Acil Tıp Dergisi. 2009; 8: 15-20.

16. Fatema K, Bailey $\mathrm{KR}$, et all. Increased Left Atrial Volume Index: Potent Biomarker for First-Ever Ischemic Stroke. Mayo Clin Proc. 2008; 83: 1107-14.

17. Hillbom M, Numminen H, Juvela S. Recent heavy drinking of alcohol and embolic stroke. Stroke. 1999; 2307-2312, 30.

18. Sümer M, Özdemir İ, Ertürk Ö, Progression in acute ischemic stroke: frequency, risk factors and prognosis. Journal of Clinical Neuroscience. 2003; 10: 177-80.

19. Efstathiou SP, Tsioulos DI, Zacharos ID, et all. A new classification tool for clinical differentiation between haemorrhagic and ischaemic stroke. J Intern Med. 2002; 121-9.

20. Chalela JA, Kidwell CS, Nentwich LM, et all. Magnetic resonance imaging and computed tomography in emergency assessment of patients with suspected acute stroke: a prospective comparison. Lancet. 2007; 369: 293-8.

21. Ross R. Atherosclerosis--an inflammatory disease. N Engl J Med. 1999; 340: 115-26.

22. Sharp DS, Benowitz NL, Bath PM, et all. Cigarette smoking sensitizes and desensitizes impedancemeasured ADP-induced platelet aggregation in whole blood. Thromb Haemost. 1995; 74: 730-5.

23. Deveci Ş, Çelebi A, Aşkın S, ve ark. Akut iskemik inme ile ortalama trombosit hacmi ilişkisi, Ege Tıp Dergisi. 2014; 53: 1-6. 
24. Güldiken B, Özkan H, Kabayel L. Akut İskemik İnmede Ortalama Trombosit Hacmi ve Periferik Kan Hücre Sayısı Yanıtı. Trakya Univ Tip Fak Derg. 2008; 25: 130 5.

25. O'Malley T, Langhorne P, Elton RA, Stewart C. Platelet size in stroke patients. Stroke. 1995; 26: 995-9.

26. Tohgi H, Suzuki H, Tamura K, et all. Platelet volume, aggregation, and adenosine triphosphate release in cerebral thrombosis. Stroke. 1991; 22: 17-21.

27. Koyuncu F, Cander B, Girişkin S, ve ark. İskemik inme etyolojisinde kardiyak ve karotis patolojile-rinin yeri ve önemi. JAEM. 2011; 10: 114-8.
28. Schaefer PW, Copen WA, Lev MH, et all. Diffusion Weighted İmaging in Acute Stroke. Neuroimaging Clinics of North America. 2005; 15: 503-530.

29. Bath PM. The routine measurement of platelet size using sodium citrate alone as the anticoagulant. Thromb Haemost. 1993; 70: 687-90.

30. Roffe C, Sills S, Wilde K, et all. Effect of hemiparetic stroke on pulse oximetry readings on the affected side. Stroke. 2001; 32: 1808-10. 